\title{
INDONESIAN GOVERNMENT POLICY AND SMEs BUSINESS STRATEGY DURING THE COVID-19 PANDEMIC
}

\author{
Ratnaningsih Hidayati ${ }^{1 *}$, Nadya Megawati Rachman ${ }^{1)}$ \\ 1) Center for Trade Education and Training Ministry of Trade \\ *Correspondence Author: ratna.hidayati@kemendag.go.id \\ Email: nadya.megawati@kemendag.go.id
}

\begin{abstract}
Economic disruption by The COVID-19 pandemic has hit Indonesian economic heavily. The purpose of this study is to provide an overview of government policies and business strategies in Indonesia amid the COVID-19 pandemic. This study employed a qualitative approach with data sources of literature reviews. The results of the study indicate that the Indonesian Government has responded to the pandemic by issuing some policies regarding SMEs. There are several policies issued regarding the Micro and SMEs business. The policy is breakdown into five schemes namely (1) Social support; (2) SMES tax incentives; (3) Credit restructuring and relaxation (4) Working capital support stimulus; and (5) Collaboration with State-owned enterprise as the off-taker for SMES products. On the other hand, there are some SMES business strategies in adjusting amidst the Covid-19 pandemic in Indonesia. Those strategies are (1) Products innovation; (2) Customer and stakeholder relationship management;(3) Digital marketing and distribution; and (4) Strategic Agility.
\end{abstract}

Keywords: COVID-19, Business, Policy, Strategy 


\section{INTRODUCTION}

COVID-19 is caused by a coronavirus which attacks the respiratory system. This virus first appeared in China's Wuhan Province in December 2019. Then cases of transmission of this virus developed very quickly even to various countries, and now it is a pandemic, sweeping the entire world. The COVID-19 pandemic has had a tremendous impact on the world economy and has even changed the order of life before 2020.

Various policies in the economic sector have been issued by governments around the world to respond to the COVID-19 pandemic. However, until now there has been no single effective policy formula that can be applied by the majority of countries in the world because this health problem is closely related to the habits of life and social order in society.

The pandemic that started in China has destroyed most of the economic foundation in various countries. Currently, China's influence on world trade is enormous. As one of the world's industrial centres, China has become a strategic trading partner for almost all countries in the world. The sluggish trade sector, due to the COVID-19 pandemic, does not only affect large-scale industries. The Small and Medium Enterprises sector is also affected by the impact of various policies implemented in place to anticipate the spread of this virus so that the area of infection does not spread. Lockdown policies in various countries have limited the space for the community to move. As a consequence, many SMEs have not been able to adapt to current conditions and temporarily close their businesses, and further face cash flow constraints, including SMEs in Indonesia.

Based on data from the UNDP Indonesia website posted on July 7, 2020, most SMEs in Indonesia are driven by young entrepreneurs. The results of a survey conducted by UReports (Diandra \& Rahmatullah, 2020) of 756 young entrepreneur respondents in Indonesia regarding the impact of COVID-19, are as follows:

1. $79 \%$ of respondents reported that COVID19 had a negative impact on the businesses. Of these, as many as $21 \%$ of respondents stated that their business had actually stopped because of the spread of the corona virus.
2. As many as $58 \%$ of respondents stated that they experienced a decline in turnover of up to $81 \%$.

3. Support from the government has been received by $32 \%$ of respondents. The Indonesian government has allocated funds 677 trillion for fiscal stimulus, which consists of tax reduction, access to credit and loans, social protection support, rapid COVID-19 testing, support for utility payments and fulfillment of daily needs as well as organizing online training / seminars (webinars).

This study aims to describe SMES business strategy in Indonesia as well as the Government policy concerning the SMEs amid the COVID-19. Besides, this study is also expected to provide an overview both for the Government and SMEs business to survive during the decreasing economic growth and to recover with some adjustment in macro or microeconomic scale towards the new normal era.

\section{LITERATURE REVIEW}

Small and medium-sized enterprises (SMEs), have been recognized as the backbone of economic growth. The role of SMEs in fostering endogenous sources of growth and strengthening infrastructures for rapid economic expansion and development is acknowledged because of their sheer amount, scale, and the existence of operations. The interdependence between small and big firms has contributed to the continued growth of small and medium-sized corporations.

(Aris, 2007) stated that Small and mediumsized companies could promote domestic development in new and emerging sectors and improve economic stability in a dynamic, demanding climate. SME activities have produced substantial economic growth in developing countries, including Japan, Korea, Taiwan and many others. SMEs 'contribution to the GDP / total added benefit varies from $60.0 \%$ in China, $57 \%$ for Germany, $55.3 \%$ for Japan, $50.0 \%$ for Korea and $47.3 \%$ for Malaysia. SMEs' contribution to the Gross Domestic Product (GDP). 
(Hu, 2010) has compiled data covering thirtyseven countries over the period from the 1960s to the 1990s. These samples cover different categories of countries and territories, in particular concerning their level of economic growth. The empiric data indicates the hierarchical association between small and medium-sized businesses and economic development, with the SME sector having some significant relevance to economic growth. The study also explored whether or not there are any distinctive characteristics of the nature of the systemic relationship between the SME sector and economic development in both developed and developing economies, and believe that the empiric analysis confirms this statement. Entrepreneurship, inherited from the SME market, leads to economic growth in developed economies. In contrast, the importance of the SME sector in terms of job creation is the major contributor to economic growth in developing countries.

In Indonesia, small and medium-sized enterprises have traditionally played a leading role in domestic economic activities, in particular as a large provider of job opportunities and as a source of primary and secondary revenue for many families. Small Enterprises units of less than 20 non-farm employees are particularly essential for lowand marginal farm households in rural areas. These businesses were also an essential mechanism for the growth of local economies and communities (Tambunan, 2008).

Based on data from the Ministry of Cooperatives and SMEs in 2018, Indonesian SMEs are a critical backbone of the economy. The structure of the Indonesian economy shows that around $99 \%$ of company profile consists of the SMES sector. This sector also absorbs approximately $97 \%$ of the total workforce in the economic sector. Moreover, according to data from the Central Statistics Agency (BPS), the contribution of SMEs to Products Indonesia's Gross Domestic Product (GDP) reaches 61.41 per cent in 2018. This contribution highlighted the role of SMEs as the backbone of Indonesia's national economy (Pakpahan, 2020)

In 2019 the contribution of SMEs to national gross domestic product grew in numbers by $5 \%$, additionally quoted from the web The Ministry of Cooperatives and SMEs targeted at the end of 2020 contributions SMEs of export value also increased to $18 \%$ from the previous figure, $14 \%$, with a $4 \%$ increase. The contribution figure of SMES to national GDP also predicted to increase, and the entrepreneurship ratio number is $3.55 \%$. (Marlinah, 2020)

During the Covid-19 pandemic, according to the Indonesian Ministry of Cooperatives and Small and Medium Enterprises, around 37000 SMEs were heavily impacted. Approximately 56 per cent of the data reported are related to falling revenue, 22 per cent to financial access, 15 per cent to product distribution and 4 per cent to access raw materials (Rahman, 2020). This condition has brought several consequences both to the economic growth and the SMEs business sustainability.

\section{RESEARCH METHODOLOGY}

this research uses a qualitative approach. The data collection technique was carried out through relevant literature studies taken from several sources both printed and electronic media, books, and research results accessed from various electronic journals, and secondary data obtained from desk research

\section{RESULTS AND DISCUSSIONS}

\section{Government Policy Respond}

According to the report from the Organization for Economic Co-operation and Development (OECD), the Covid-19 pandemic is affecting the economy from the supply and demand side. On the supply side, companies reduce the supply of raw materials and unhealthy labour and supply chains that are also experiencing constraints. From the demand side, lack of demand and decreasing consumer confidence in a product. OECD also stated that SMEs had a significant impact on the conditions of 
Covid-19. SMEs were very vulnerable to being affected by business disruptions because they often had direct contact with tourism, transportation and the culinary industry that needed them. Fast suppliers, all of which have been significantly affected by COVID-19 (OECD, 2020). Therefore, the Government should take initiatives to create a conducive environment for economic recovery and provide more support to the SMEs.

COVID-19 is not just a global public health emergency; it has been a regional economic disaster that might surpass the 2008-09 global financial crisis. Nowadays, prevention and mitigation measures are required to reduce the transmission of the virus and save lives. They come at an expense, though, as shutdowns mean a decrease in economic development. These human and economic costs are likely to be higher for developed countries that traditionally have lower health care potential, more significant informal industries, lower capital reserves, less fiscal space, and weaker governance. Policymakers may need to consider the efficacy closely and socioeconomic implications of containment and control strategies, react to epidemiological data about how the virus spreads and aim and prevent unforeseen effects. In the near term, economic policy should concentrate on delivering humanitarian aid to distressed communities and impacted companies. The short-term aim is not to boost the economy which, considering supply-restricting containment policies, is impossible — but rather to stop widespread unemployment and bankruptcies. In the medium term, macroeconomic policy should be oriented towards stabilization steps that usually include monetary and fiscal stimuli. However, the stimulus could be less successful in many developed countries, since monetary diffusion is slow and fiscal room and fiscal multipliers are also limited. A more feasible aim for macroeconomic policy in developed countries is to prevent procyclicality, guarantee the sustainability of public utilities for the market and protect the poor. Since COVID-19 is genuinely a global shock, international collaboration is essential in economic policy, health care and research, as well as containment and mitigation efforts. Sensitive times call for well-designed government policy and efficient implementation of public services - preserving, rather than denying, macroeconomic stability and strong governance principles that work in good and poor times (Loayza \& Pennings, 2020).

The Government of Indonesia has prepared five schemes for financial protection and recovery for the micro, small and medium enterprises sector (SMEs). Several schemes which also include a particular program for ultra SMEs are prepared with the hope that SMEs can survive amid the Covid-19 pandemic (Marlinah, 2020). These schemes are:

1. The first scheme is for small and medium enterprises which categorized as poor and vulnerable to being affected by Covid-19. Efforts made to ensure that business actors in this scheme become recipients of social assistance from the Government. According to Minister of Social Affairs Number 1/2018, Government must ensure that they are included as part of the recipients of social support namely PKH (Family Hope Program), food packages, cash assistance, direct cash support, as well as exemption from reducing electricity rates and pre-employment cards.

2. The second scheme is a scheme regarding tax incentives that applies to SMES actors with a turnover revenue of below Rp. 4.8 billion per year. The Government has lowered the final income tax rate (the final Pajak Penghasilan (tax income) or PPh rate) for SMEs from 0.5 to 0 per cent over six months starting from April to September 2020 this policy written in Minister of Finance Regulation (Peraturan Menteri Kuangan) Number 44/PMK.03/2020.

3. The third scheme is relaxation and SMES credit restructuring. This scheme includes the postponement of instalments and 
interest subsidies for recipients of KUR (People's Business Credit), UMi (Ultramicro Credit), PNM Mekaar (Permodalan Nasional Madani Fostering Prosperous Families), LPDB (revolving fund management institutions), and recipients of capital support from several ministries. The first SMES credit restructuring was carried out by relaxing asset quality assessments based on Financial Services Authority Regulations Number 11 / POJK.03 / 2020 and 14 / POJK.05 / 2020. Assets quality in loans of up to IDR 10 billion can only be based on the accuracy of principal/interest payments. Additionally, restructuring was carried out, namely debtor credit affected by Covid-19 was determined to be current since it was restructured and restructuring was carried out without a ceiling limit/type of financing. UMKM credit restructuring was also carried out by postponing principal and subsidies. This policy received a legal umbrella from the Minister of Finance Regulation Number 65 / PMK.05 / 2020 which was later updated with PMK Number 85 / PMK.05 / 2020.

4. The fourth scheme, the Government will also impose expansion financing support for SMEs, in the form of working capital assistance stimulus. The Government prepares emergency working capital assistance designed explicitly for SMES entrepreneurs who are severely impacted by Covid-19. The data shows that currently, there is 41 million SMES business have already connected with financial institutions and banks. Meanwhile, there are still 23 million SMEs who have never received financing from financial institutions or the banking system. Therefore, for SMEs that are bankable, the financial support distribution will go through the expansion of the KUR program and at the same time encourage financial inclusion. On the other hand, for those who are not bankable, the distribution can be done through UMi, Mekaar, or other program schemes

5. The fifth scheme, through the ministry, State-Owned Enterprises and local government institutions. These agencies will act as a buffer in the SMES ecosystem at the stage of recovery and business consolidation during and after the Covid-19 pandemic. For example, State or region owned enterprise become an off-taker (absorber) for the production of SMES business in the fields of agriculture, fisheries, culinary, to home industries. President also strongly reminds the local governments to reallocate the budget and refocus it to the economic stimulus program regarding the SMES sector.

\section{Indonesia SMEs Business Strategy during Covid-19 Pandemic}

One of the most significant determinants of success for SMEs is their flexibility in paying close attention to the needs and expectations of customers. When there are drastic changes caused by this pandemic, many business models or businesses cannot survive, but new opportunities will be created (Venkatesh, 2020). In this condition, it is understandable if SMEs find it very difficult to focus on identifying and exploring new opportunities with lost profits, customers and even key employees. However, with the survival of the SMEs at stake, owners must exercise resilience and adopt a mindset to recognize and identify opportunities to bounce back and move forward. The following are the business strategies carried out by Indonesian SMES in dealing with the COVID-19 pandemic:

\section{Products innovation}

(Kumala \& Junaidi, 2020) explained that in Indonesia, SMEs entrepreneurs' corporate strategy is product innovation. In time of the Covid-19 pandemic, the business opportunity will likely increase in-store online sales. Therefore, they need to offer various innovative products. Process innovation also a vital part to increase efficiency. The production process will be more effective and efficient if there is a standardization of value chain activities such as design, sourcing, manufacturing, and retail instead of designing products to meet specific markets. Hence, (Lee \& Marvel, 2009) described that most of South Korean SMEs have successfully implemented 
this cost leadership strategy by expanding their volume through internationalization in overseas markets

\section{Service quality improvement}

Apart from paying attention to consumers, it is also necessary to pay attention to the team or partners. Based on the survey conducted in the research, SMES actors maintain Good relations with partners, among others, with suppliers and distributors (Nugraheni et al., 2020). Maintaining relationships with existing customers is essential for business actors, and communicating effectively with customers is the key to building trust (Liguori \& Pittz, 2020). Also, (Kwaku \& Satyendra, 1998) explained that a combination of customer orientation and an innovation strategy has a beneficial effect on the performance of the new product. In exchange, it raises sales growth. There is a correlation between customer orientation and product quality which, in turn, affects efficiency. Delivering consistently high-quality products and services to customers could allow the SMEs to gain a sustained competitive edge in the marketplace. The significance of the effect of customer orientation on performance in small and medium-sized enterprises demonstrates the need for a deeper understanding of the organizational factors that decide the degree and shape the direction of a customer-oriented culture within the business. The results of this study suggest it is the high levels of market dynamism and competitive intensity does not seem to result in increased concentration on customer-oriented strategies for small and medium-sized enterprises. While some companies are expected to participate in intensified customer-oriented practices under highly volatile or challenging environments, others may pursue cost or price-cutting strategies to compensate or adapt to competitive pressures. However, it must be borne in mind that the benefits of such initiatives are supposed to be short-lived and, over the long term, they have little impact on profitability. A high degree of concentration on innovation appears to be related to a higher level of consumer orientation since dedication to innovation would cause a business to become actively based and therefore, more customer-oriented. The outward emphasis would also allow the firm to find more business opportunities relative to its competitors, who are characterized by a low level of customer orientation and an internal focus.

\section{Strengthen the collaboration}

SMES actors recognize that collaboration with partners is necessary for the development of their businesses. Collaboration with partners can also be used to get new ideas, and when businesses need help. The collaboration is carried out by associating with organizations with SMEs in similar fields to expand business networks(Agus Setiono, 2020). Moreover, (Lasagni, 2012) argues that the performance of innovation is higher for SMEs who work to strengthen relations with innovative providers, users and customers. Also, the findings of this paper support the view that, if they improve relations with laboratories and research institutes, SMEs will have better new product development results

\section{Utilize the Technology}

Many of the Indonesian SMEs Entrepreneurs have already familiar with technology to boost their productivity and sales. The hard time during Covid-19 pandemic is accelerating the technology and e-commerce adoption among the SMEs Entrepreneurs. Online sales and online marketing are forms of utilizing technology. Through e-commerce, a new digital market with easy access, more transparent and more efficient can be created. The SMEs entrepreneurs can use several ecommerce sites in Indonesia include Shopee, Tokopedia, Bukalapak, Lazada, Blibli and many other marketplace e-commerce. Ecommerce influences on improving the performance of SMEs, namely by reducing transaction costs and coordinating economic activities between business partners (Hanum \& Sinarasri, 2018). Also, to meet market 
objectives and to improve SMEs goods or services, the correct digitalization approach is essential to be more successful. Cultural complexity, plurality and collective encouragement are the economic advantages. Digital networks must be thoroughly checked in the course of the digital transition. The measures to be taken in digital transformation in small and medium-sized companies are as follows: 1) the right approach and general perception, 2) the right lead, 3) the launch of a superior digital business hub, 4) the implementation of a digital plan, 5) the implementation, information acquisition and exploration, and 6) the emergence of new digital ability (Casalino et al., 2015)

\section{Strategic Agility}

Strategic Agility is the company's ability to respond quickly to changing environmental conditions (Gerald et al., 2020). Flexibility in the company's operational response to discontinuity and volatility in the environmental business defines a company's Strategic Agility. Companies with Strategic Agility capabilities can successfully predict and adapt to new opportunities and threats. In line with this, (Mavengere, 2013) argues that Strategic Agility is related to organizational sensitivity or being armed with foresight to understand and predict new events in the environment in which the organization operates. It is the strong ability to identify and react to environmental opportunities and threats with prosperity, speed, and agility. (Shin et al., 2015; Tallon \& Pinsonneault, 2011) in their research on the effect of strategic agility on firm's performance and operations states that strategic agility shows a more substantial direct effect as well as indirect (mediation) effect through operational responsiveness to customer retention.

Conversely, strategic agility does not affect financial performance either directly or indirectly through operational responsiveness. (Yun et al., 2015) stated that SMEs could not survive if they do not accept open innovation in knowledge strategies and business models.
SMEs that exhibit absolute limitations in resources and human resources should adopt an open innovation strategy to secure a more diverse resource from the external market and knowledge base rather than preparing all their resources and capabilities.

\section{CONCLUSION}

Indonesian SMES business has severely hit by the COVID 19 pandemic. This situation demanded the SMEs to implement business strategies in order to survive. Those strategies are (1) Innovation; (2) Customer and stakeholder relationship management;(3) Digital marketing and distribution;(4) Strategic Agility. On the other hand, the Indonesian Government has responded to the pandemic by issuing some policies regarding SMEs. There are several policies issued and breakdown into five schemes namely (1) social support; (2) SMEs tax incentives; (3) Credit relaxation and restructuring (4) working capital assistance stimulus; and (5) Collaboration with Stateowned enterprise to absorb SMEs production. Due to the Pandemic situation, the data is limited to the desk research and literature review. More comprehensive research with primary data with sufficient sample is very much recommended for further analysis. This study will be useful for the Indonesia Government Agency whose duty is to provide assistance and support for SMEs to formulate a high impact and reliable policy and programs to provide a safety net for economic recovery, particularly for the SMEs Sector.

\section{REFERENCES}

Agus Setiono, B. (2020). Strategi Bertahan Bagi UKM Hadapi Krisis Akibat Covid19.

Aris, N. M. (2007). SMEs: Building blocks for economic growth. Department of National Statistics, Malaysia.

Casalino, N., De Marco, M., \& Rossignoli, C. (2015). The extensiveness of manufacturing and organizational processes: an empirical study on workers employed in the European SMEs. In 
Smart Education and Smart e-Learning (pp. 469-479). Springer.

Diandra, Lady, \& Rahmatullah, Y. F. (2020). Result of Survey on Impact of COVID-19 on Youth Entrepreneurs in Indonesia Entrepreneurs (Issued June 2020UNDP).

https://www.undp.org/content/dam/indon esia/2020/DOCS/INS-Report-survey-onimpact-of-COVID19-to-YE-inIndonesia.pdf

Gerald, E., Obianuju, A., \& Chukwunonso, N. (2020). Strategic agility and performance of small and medium enterprises in the phase of Covid-19 pandemic. International Journal of Financial, Accounting, and Management, 2(1), 4150.

Hanum, A. N., \& Sinarasri, A. (2018). Analisis faktor-faktor yang mempengaruhi adopsi e commerce dan pengaruhnya terhadap kinerja umkm (studi kasus umkm di wilayah kota semarang). MAKSIMUM, $8(1)$.

Hu, M.-W. (2010). SMEs and economic growth: entrepreneurship or employment. ICIC Express Letters, 4(6), 2275-2280.

Kumala, R., \& Junaidi, A. (2020). Strategi Bisnis Dan Pemanfaatan Kebijakan Pajak Di Masa Pandemi COVID-19 Dan Era New Normal (Studi Kasus Pelaku UKM Marketplace). Prosiding Seminar STIAMI, 7(2), 98-103.

Kwaku, A., \& Satyendra, S. (1998). Customer orientation and performance: a study of SMEs. Management Decision, 36(6), 385-394.

https://doi.org/10.1108/00251749810223 592

Lasagni, A. (2012). How Can External Relationships Enhance Innovation in SMEs? New Evidence for Europe*. Journal of Small Business Management, 50(2), 310-339.

https://doi.org/10.1111/j.1540627X.2012.00355.X

Lee, I. H., \& Marvel, M. R. (2009). The moderating effects of home region orientation on $R \& D$ investment and international SME performance: Lessons from Korea. European Management Journal, 27(5), 316-326. https://doi.org/10.1016/j.emj.2009.04.011

Liguori, E. W., \& Pittz, T. G. (2020).
Strategies for small business: Surviving and thriving in the era of COVID-19. Journal of the International Council for Small Business, 1-5.

Loayza, N. V, \& Pennings, S. (2020). Macroeconomic policy in the time of COVID-19: A primer for developing countries. World Bank.

Marlinah, L. (2020). Peluang dan Tantangan UMKM Dalam Upaya Memperkuat Perekonomian Nasional Tahun 2020 Ditengah Pandemi Covid 19. JURNAL EKONOMI, 22(2), 118-124.

Mavengere, N. (2013). Information systems role in strategic agility: A supply chain context.

Nugraheni, A. P., Pramudyastuti, O. L., \& Sunaningsih, S. N. (2020). STRATEGY OF SMEs IN THE COVID-19 PANDEMIC PERIOD. Jurnal Akuntansi \& Perpajakan Jayakarta, 2(1), 45-52.

OECD. (2020). SME Policy Response. https://read.oecd-

ilibrary.org/view/?ref=119_119680-

di6h3qgi4x\&title=Covid -

19_SME_Policy_Responses

Pakpahan, A. K. (2020). COVID-19 DAN IMPLIKASI BAGI USAHA MIKRO, KECIL, DAN MENENGAH. Jurnal Ilmiah Hubungan Internasional. https://doi.org/10.26593/jihi.v0i0.3870.59 $-64$

Rahman, R. (2020). 37,000 SMEs hit by COVID-19 crisis as Government prepares aid. April. https://www.thejakartapost.com/news/20 20/04/16/37000-smes-hit-by-covid-19crisis-as-government-prepares-aid.html

Shin, H., Lee, J. N., Kim, D., \& Rhim, H. (2015). Strategic agility of Korean small and medium enterprises and its influence on operational and firm performance. International Journal of Production Economics, 168, 181-196. https://doi.org/10.1016/j.ijpe.2015.06.015

Tallon, P. P., \& Pinsonneault, A. (2011). Competing perspectives on the link between strategic information technology alignment and organizational agility: insights from a mediation model. Mis Quarterly, 463-486.

Tambunan, T. (2008). SME development, economic growth, and government intervention in a developing country: The 
Indonesian story. Journal of International Entrepreneurship, 4(6), 147-167.

Venkatesh, V. (2020). Impacts of COVID-19: A research agenda to support people in their fight. International Journal of Information Management, 102197.

Yun, J. J., Jung, W., \& Yang, J. (2015). Knowledge strategy and business model conditions for sustainable growth of SMEs. Journal of Science \& Technology Policy ManagementManagement, 6(3), 246-262 